\title{
NOTES ON ALKALI SOIL IN MONTANA.
}

BT.F, W, TRAPBAGEN AND W. M. COBLEIGR.

Rectived April $24,1899$.

G VEN the most casual observer, passing through the state by L rail, must have been more or less impressed by the appearance of occasional spots, barren of vegetation, and incrusted with a white, red or yellow salt, which are to be seen at various points in Montana. These are the so-called "alkali" soils, and represent the worst phase of the condition.

The agriculturist recognizes two kinds of alkali : the "white" and the "black," the former consisting mainly of sodium sulphate and the latter of sodium carbonate.

A solution of the "black" alkali, on account of its solvent action upon organic matter, dissolves the humus from the soil, and upon evaporation leaves it as a shiny black coating upon the surface, or in black concentric rings around the pools in which it collects. Vegetation is destroyed by contact with solutions of sodium carbonate, the stems, especially at the surface of the ground, being frequently completely girdled. Hilgard has found that as little as one-tenth per cent. sodium carbonate in the surface foot is deleterious.

On the other hand a much larger amount of the "white" alkali may exist without affecting vegetation injuriously. In Montana, the alkali consists almost entirely of sulphates and rarely possesses a strong alkaline reaction. I have found crops thriving in the presence of as much as six-tenths per cent. of the "white" alkali. The "white" alkali seems to produce its injurious effects when present in excess, not through any chemical influence, but rather by interference with the process of osmosis by which the plant obtains its mineral food and water, the external solutions frequently becoming of much greater density than the sap.

The following analyses of typical alkali soils of the Yellowstone Valley, will give an idea of the salts usually present and their relative proportions.

Sample No. 372, from Hesper Farm, uncultivated portion, taken at fourteenth foot in depth, about the center of "zone of 
concentration." The figures give actual percentage of constituents soluble in water.

\section{SAMPLE NO. 372 , HESPER FARM.}

Per cent.

Soluble silica............................. 0.004

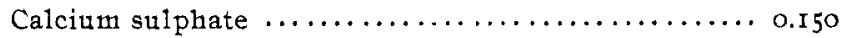

Magnesium sulphate $\ldots \ldots \ldots \ldots \ldots \ldots \ldots \ldots \ldots \ldots \ldots$ o. $3^{\circ}$

Potassium sulphate......................... 0.009

Sodium sulphate $\ldots \ldots \ldots \ldots \ldots \ldots \ldots \ldots \ldots \ldots \ldots \ldots, 0.320$

Sodium nitrate $\ldots \ldots \ldots \ldots \ldots \ldots \ldots \ldots \ldots \ldots \ldots \ldots, 0.018$

Alkaliuity in terms of sodium carbonate.......... 0.096

Sample No. 304, Surface Crust.

\begin{tabular}{|c|c|}
\hline & Per cen \\
\hline & 0.054 \\
\hline alcium sulphate $\ldots \ldots \ldots \ldots \ldots \ldots \ldots \ldots \ldots \ldots \ldots$ & 1.28 \\
\hline lagesium sulphate................... & 14.91 \\
\hline 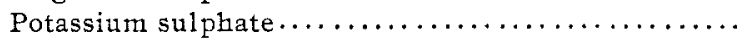 & 0.83 \\
\hline odium sulphate..$\ldots \ldots \ldots \ldots \ldots \ldots \ldots \ldots \ldots \ldots \ldots \ldots$ & 26.65 \\
\hline 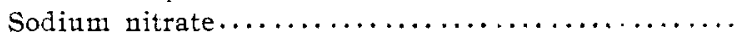 & trace \\
\hline odium chloride...$\ldots \ldots \ldots \ldots \ldots \ldots \ldots \ldots \ldots \ldots \ldots$ & 0.637 \\
\hline terms of sodium carbonate....... & 0.144 \\
\hline
\end{tabular}

SAMPle, No. 405, SURface Crust.

Per cent.

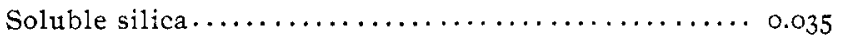

Calcium sulphate......................... ${ }_{3} 8$

Magnesium sulphate $\ldots \ldots \ldots \ldots \ldots \ldots \ldots \ldots \ldots \ldots \ldots, 2 \mathrm{\ldots}$

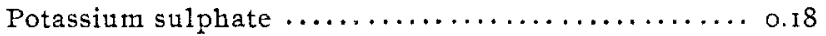

Sodium sulphate $\ldots \ldots \ldots \ldots \ldots \ldots \ldots \ldots \ldots \ldots \ldots \ldots, 6.43$

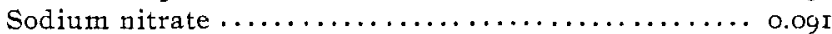

Sodium chloride $\ldots \ldots \ldots \ldots \ldots \ldots \ldots \ldots \ldots \ldots \ldots . \ldots \ldots \ldots$

Alkalinity in terms of sodium carbonate........... 0.048

It will be seen that the actual percentage of soluble matter present varies very greatly, but the ratios of the quantities of the different salts is remarkably constant.

All regions of deficient rain-fall are subject to the accumulation of soluble salts in their soils, for, unlike humid sections, there is an insufficient quantity of water to carry off the salts rendered soluble by the natural processes of rock-disintegration.

Add to this the presence of rocks of marine origin which have been deposited in the presence of sulphates and chlorides, and you have a fruitful source of soluble alkali salts.

Analyses of the Fort Benton shales, bordering the Yellowstone 
Valley, show the presence of considerable quantities of soluble sulphates. The percentages calculated to sodium sulphate range from 1.03 to 2.02 . As these rocks, by their decomposition, contributed very largely to the formation of the soils of the Valley, the source of the "alkali" is readily apparent.

Where the soil exists in its virgin condition, undisturbed by plow or irrigation, the alkali is present at a considerable depth, being practically all concentrated in a particular zone. The series cited below was obtained from a point above the line of the ditch, and in consequence had never been irrigated, and further because of this no attempts at cultivation had ever been made.

Samples from Uncultivated PORTion of Hesper Farm.

\begin{tabular}{ccccc} 
Lab. No. & Depth in inches. & $\begin{array}{c}\text { Sodium sulphate. } \\
\text { Per cent. }\end{array}$ & $\begin{array}{c}\text { Alkalinity in terms of } \\
\text { sodium carbonate. } \\
\text { Per cent. }\end{array}$ & $\begin{array}{c}\text { Moisture. } \\
\text { Per cent. }\end{array}$ \\
359 & $0-12$ & 0.016 & 0.025 & 3.40 \\
360 & I2- 24 & 0.006 & 0.021 & $4 \cdot 30$ \\
$36 \mathrm{r}$ & $24-36$ & Trace & 0.032 & 3.50 \\
362 & $36-48$ & 0.015 & 0.021 & 3.50 \\
363 & $48-60$ & 0.045 & 0.017 & $\ldots$ \\
364 & $60-72$ & 0.077 & 0.014 & $\ldots$ \\
365 & $72-84$ & 0.094 & 0.021 & $\ldots$ \\
366 & $84-96$ & 0.123 & 0.014 & $\ldots$ \\
367 & $96-108$ & 0.104 & 0.014 & $\ldots$ \\
368 & $108-120$ & 0.115 & 0.025 & $\ldots$ \\
369 & $132-144$ & 0.288 & 0.021 & $\ldots$ \\
370 & $144-156$ & 0.379 & 0.017 & $\ldots$ \\
371 & $156-168$ & 0.737 & 0.010 & $\ldots$ \\
372 & $168-180$ & 0.780 & 0.017 & $\ldots$ \\
373 & $180-192$ & 0.745 & 0.014 & $\ldots$ \\
374 & $192-204$ & 0.605 & 0.017 & $\ldots$ \\
375 & $204-216$ & 0.574 & 0.014 & $\ldots$ \\
376 & $216-228$ & 0.458 & 0.010 & $\ldots$ \\
\hline
\end{tabular}

With the advent of irrigation, the salts, usually deeply located, begin to rise to the surface. The water table formerly many feet deep approaches nearer and nearer to the surface, and of course brings the soluble salts with it.

An example illustrating the rise of the ground water may not be out of place here. In 1882, Mr. Hiram Abshire, whose ranche is near the middle of the valley, dug a well finding water at a depth of thirty-one feet; in September, 1897 , fifteen years 
later, the water had risen to within six feet of the surface. This is but one of many similar cases.

Samples taken from fields located on opposite sides of the main ditch show the zone of concentration of the soluble salts to be considerably deeper above the ditch than below it, and this is true even though the fields have never been irrigated.

Irrigation has the effect of concentrating the salts at the surface, for of course that which the water dissolves in its down. ward course, is brought up by it again when it rises by capillary action to supply surface losses due to evaporation. When it in turn evaporates, its salts are left upon the surface.

The following examples illustrate strikingly this action.

$$
\text { Alfalfa Fiet.d, IRRIGATEd, FAIR CROP. }
$$

\section{Iab. No.}

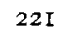

222

223

224

225

226
Depth in inches.

$$
\text { O-I } 2
$$

I $2-24$

$24-36$

$36-57$

$57-7^{2}$

$72-90$

\section{sodium sulphate. Per cent.}

0.140

0.198

0.039

0.036

0.036

0.039

Alkalinity in terms of sodium carbonate Per cent.

0.017

0.014

0.014

0.014

0.017

0.017

Blue Joint Field, Unirrigated, Used for Pasture. Across Road FROM PREVIOUS LOCALITY.

$\begin{array}{cccc}\text { Lab. No. } & \text { Depth in inches. } & \begin{array}{c}\text { Sodium sulphate. } \\ \text { Per cent. }\end{array} & \begin{array}{c}\text { Alkalinity in terms of } \\ \text { sodium carbonate. } \\ \text { Per cent. }\end{array} \\ 228 & 0-12 & 0.043 & 0.017 \\ 229 & 12-24 & 0.063 & \text { Trace } \\ 230 & 24-36 & 0.130 & 0.017 \\ 23 I & 36-57 & 0.150 & 0.010 \\ 232 & 57-72 & 0.160 & 0.017 \\ 233 & 72-90 & 0.166 & 0.017\end{array}$

An inspection of these tables will show that while there is more soluble matter in the unirrigated field than in the other, yet the relative amount in the upper portion of the soil is much greater in the irrigated field. In these two cases the field under irrigation, presumably at the outset identical with the other, has concentrated in the first twenty-four inches seven-tenths of the total soluble sodium sulphate contained within the soil to a depth of ninety inches; the samples from the unirrigated field show the presence of but fifteen per cent. of sulphate in the first 
two feet of soil, when compared with the quantity present to a depth of ninety inches. The lesser total quantity of sulphate present is to be attributed to the influence of large crops of alfalfa, which must remove with other mineral matter large quantities of alkali salts. This influence is especially marked in the case of the alfalfa field of the Hesper Farm, where two hundred and fifty acres yield twelve hundred tons of alfalfa hay annually.

Within a few feet of this field, on the east, is a field completely destroyed by "alkali," yet not only is the alfalfa field yielding immense crops, but it bids fair to continue to do so as indicated by the low percentage of alkali salts in the soil as shown in the following section:

HESPER FaRM, ALFALFA FieLd.

$\begin{array}{lcccc}\text { Lab. No. } & \text { Depth ininches. } & \begin{array}{c}\text { Sodium sulphate. } \\ \text { Per cent. } \\ \text { Alkalinity in terms of } \\ \text { Sodium carbonate. } \\ \text { Per cent. }\end{array} & \begin{array}{c}\text { Water. } \\ \text { Per cent. } \\ \text { II.50 }\end{array} \\ 377 & 0-12 & 0.012 & 0.017 & \text { II.70 } \\ 379 & 12-24 & 0.004 & 0.021 & 12.60 \\ 380 & 24-36 & 0.015 & 0.028 & \ldots \ldots \\ 381 & 36-48 & 0.013 & 0.025 & 19.00 \\ 382 & 48-60 & 0.013 & 0.025 & \ldots . \\ 383 & 60-72 & 0.019 & 0.039 & 19.50 \\ 384 & 72-84 & 0.031 & 0.039 & \ldots . .\end{array}$

Where the soil is underlain with gravel, thus affording natural underdrainage, the alkali does not rise to the surface.

This condition exists with a number of ranches in the valley, and these are singularly free from alkali.

The best method for combating the evil would appear to be underdrainage, but land is so cheap that the expense of such a remedy could not be met. Careful surface flooding, economical use of water and intelligent cropping, are the remedies in the hands of the farmer, and properly employed will solve the problem.

the Montana Fxperiment Station, BOzEMAN, MONTANA. 